\title{
Formal-informal economy linkages: What implications for poverty in South Africa?*
}

\author{
IMRAAN VALODIA \\ School of Development Studies, University of KwaZulu-Natal \\ RICHARD DEVEY \\ Statistical Consultation Service, University of Johannesburg
}

\section{INTRODUCTION}

During the almost twenty years since the transition to democracy South Africa has adopted and implemented market-friendly economic policies; yet the gap between rich and poor is growing, ${ }^{1}$ there is uneven access to the (middle class) labour market $^{2}$ and unemployment rates remain high. During the Mbeki presidency the policy debate on the South African economy was characterised as a dual economy, a "first" and "second" economy, and the Government explained the apparent paradox - of market-friendly policies associated with high levels of unemployment and poverty - through the existence of "first" and "second" economies.

In November 2003, in an address to the National Council of Provinces then President Mbeki stated:

"The second economy (or the marginalised economy) is characterised by underdevelopment, contributes little to GDP, contains a big percentage of our population, incorporates the poorest of our rural and urban poor, is structurally disconnected from both the first and the global economy and is incapable of self generated growth and development." ${ }^{3}$

The notion of dualism in South Africa came to dominate the policy debate. The extent of this can be gauged by the fact that most government departments adopted some policy addressed at the "second economy". The Presidency co-ordinated a large research project aimed at developing some coherent policies aimed at the

\footnotetext{
* We are grateful to Lekani Lebani who provided research assistance. A lot of our ideas about the informal economy have been developed through collaborative work with Caroline Skinner.

${ }^{1}$ Leibbrandt et al "Trends in South African income distribution and poverty" (2010).

2 Statistics South Africa "Profiling South African middle-class households" (2009).

3 Available at http://www.sarpn.org.za/documents/d0000830/P944-SARPN Second Economy Nov2004.pdf (accessed 8 July 2011).
} 
"second economy" which has culminated in an impressive strategic framework. ${ }^{4}$ However, in the process of formulating this framework, stakeholders have questioned the idea that the first and second economies are disconnected:

"The differences in conditions between the two are so stark they appear to be worlds apart - giving the notion of 'two economies' resonance. Yet these realities are in fact connected and interdependent in a range of complex ways, with certain common processes producing or reinforcing these extremes in access and opportunity."

Similarly, in earlier work, and in work jointly with Caroline Skinner, we have also criticised the conceptualisation of the South African economy as structurally separated. ${ }^{6}$ Instead, we argued that the economy is actually integrated and that, in part, the "two economies" idea allows government to justify its economic policies for the so-called first economy, even though little benefit accrues to most of the poor.

We are also not convinced by the lumping of both informal workers and the unemployed into the "second" economy. While both are vulnerable groups, the sets of policy interventions required to address the problems of each are likely to be somewhat different. For this reason we fall back on the multiple categorisation of formal, informal and the unemployed.

The purpose of this article is to find evidence of linkages between the formal and informal economies. In previous work we have focussed on the labour market, examining movements between the formal and informal economy. In this article, we develop this material further by exploring formal-informal linkages inside the household and we look at possible implications were we able to extend the analysis using other frameworks.

The article is presented in five sections. The context for the research is presented in the introduction. The persistence of dual models to define and measure the South African economy (and labour market) is documented in part two along with definitions of the informal economy. Findings are presented in part three, including the sectoral character of employment churning within the labour market, associations within the household, and evidence of growing informality in the work sphere. Our analysis confirms earlier concerns about conceptualising the economy in a dualist fashion. We draw out, in part four, the implications of our analysis for poverty research and development of policy in South Africa and conclude the article in part five.

\section{PERSISTENCE OF DUAL MODELS TO DESCRIBE THE ECONOMY AND THE LABOUR MARKET}

Historiography of the South African economy demonstrates that arguments about dualism and the relationship between the mainstream of the economy and the

${ }^{4}$ Phillip "Second Economy Stretegy" (2009).

${ }^{5}$ Phillip (2009).

6 Devey et al "The state of the informal economy" (2005). 
periphery have persisted over time in spite of a changing political context. This is most prominently captured in the debates of the early 1970s about the relationship between apartheid and capitalism in South Africa, with liberals arguing that capitalism would ultimately undermine apartheid as more and more of the African periphery came to be incorporated into the mainstream of the economy, ${ }^{7}$ and Marxists arguing that there was in fact a close, but exploitative, relationship between the mainstream and the periphery. ${ }^{8}$ In the mid-1980s the state continued to distinguish between a "modern" sector and the informal economy. ${ }^{9}$ This dualism persists through the notion of first and second economies.

The persistence of a dualist view of the economy is significant not only because it was being articulated by the then President and is at odds with the way in which the ANC has traditionally viewed South African society, but also because it seems to inform much of the policy focus of the ANC. This conceptualisation of the economy has strong resonance with the dual labour market theories which emerged in the early 1970s. Thus, today's first economy shares characteristics of the primary or core economy of the 1970s - stable, preferential employment conditions found with large-scale, capital intensive and advanced production process, an elaborate division of labour and hierarchy within the firm, and skilled and highly motivated well-paid workers with promotion prospects. ${ }^{10}$ Similarly, today's second economy shares characteristics of the secondary (or peripheral) economy of the 1970s insecure employment in small-scale, backward firms with limited prospects for workers.

An alternative to the dual economy conceptualisation is to view the economy as a single entity. We agree the notion of a "second" economy is not helpful as an analytical category but there is also a danger in grouping the formal and informal in one economy. Chen, Vanek and Carr ${ }^{11}$ have called for greater recognition of informal work, noting that the quantity and quality of work generated are key determinants of the poverty and equity outcomes of different patterns of economic growth. In his book Work Svendsen ${ }^{12}$ focuses on work in the western context, stating that "to cover the working conditions of people in the developing world would be an altogether different essay". In a survey intended to measure the contribution agriculture makes to GDP in South Africa, Statistics South Africa samples "registered" farms only.

These examples give support to Chen et al's concern that, while formal work gets significant attention, informal and difficult-to-categorise employment is often either undervalued or omitted from conceptualisation and measurement of the value of employment. To redress this tendency we justify the use of "formal" and "informal" as analytical categories to (1) establish the significance of the informal economy, (2) provide a framework to include less obvious types of work, and (3) expose the

\footnotetext{
${ }^{7}$ Lipton Capitalism and Apartheid (1985) and O'Dowd, "The Stages of Economic Growth" (1978)

8 Legassick "South Africa: Capital accumulation and violence" (1974) and Wolpe "Capitalism and cheap labour power in South Africa (1972)

9 Booth "Measuring the 'success' of employment creation strategies in the apartheid state" (1988)

10 Fine Labour Market Theory (1998)

${ }^{11}$ Chen, et al Mainstreaming informal Employment and Gender (2004)

${ }^{12}$ Svendsen Work (2008) at 3.
} 
precarious nature of informal work, all with the ultimate objective of improving job conditions of informal and (increasingly informal) formal workers. Thus, while we say the economy is integrated, it is not seen as a homogenous entity and there is space for a formal-informal categorisation.

Our analysis is to a large degree restricted by another binary categorisation, that of the "formal" and "informal" enterprise. Until recently, employment in the informal sector was based on the characteristics of the enterprise in which the person is employed. The definition of "informal economy" proposed at the $15^{\text {th }}$ International Conference for Labour Statistics (ICLS) recommended the informal sector be defined in terms of one or more of the following criteria: (a) non-registration of the enterprise in terms of national legislation such as taxation or other commercial legislation; (b) non-registration of employees of the enterprise in terms of labour legislation; and (c) small size of the enterprise in terms of the numbers of people employed. Statistics South Africa has used this enterprise-based definition in order to derive estimates of informal employment in South Africa.

More recently, the International Labour Organisation (ILO) ${ }^{13}$ and the $17^{\text {th }}$ ICLS proposed an alternative definition for the informal economy, based on the employment characteristics of the worker. According to this definition the informal economy comprises informal employment (without secure contracts, worker benefits or social protection) of two kinds. The first is informal employment in informal enterprises (small unregistered or unincorporated enterprises) including employers, employees, own-account operators and unpaid family workers in informal enterprises. The second is informal employment outside informal enterprises (by formal enterprises, by households or with no fixed employer), including domestic workers, casual or day labourers, temporary or part-time workers, industrial outworkers (including home-based workers) and unregistered or undeclared workers. This gradation is important given Altman's observation that employment in South Africa is shifting to "low wages, and fewer contractual obligations or benefits". ${ }^{14}$ In spite of this broader definition, our analysis below is based on the enterprise definition since this has generally been used to measure the informal economy.

\section{LINKAGES BETWEEN THE FORMAL AND INFORMAL ECONOMY}

Since its "discovery" in the early 1970 s, $^{15}$ the informal economy has become an important area of research. Contrary to the initial conceptualisation of the informal sector as a transitory "backward" sector which would, in line with the Lewis model, disappear with development and growth, the informal sector has become a growing phenomenon in developing countries. Unlike South Africa, most developing countries do not directly collect statistics on informal employment. Based largely on the work of French statistician, Jacques Charmes, however, we are able to form

13 ILO Women and Men in the Informal Economy (2002).

${ }^{14}$ Altman "The State of employment and unemployment" (2003).

15 Hart "Informal income opportunities and urban employment in Ghana" (1973). 
estimates of informal employment in the developing world for the 1990s. As is evident from Table 1 below, in all regions of the developing world informal employment represented nearly half of total non-agricultural employment, ranging from $72 \%$ in sub-Saharan Africa to $48 \%$ in North Africa. The norm internationally is not to include agricultural employment in these estimates. Since we know that, especially in the least developed countries, agriculture forms a large part of the economy, including this sector these is likely to increase the estimates of informal employment and also likely to increase the women's roles in the informal economy.

Table 1: Informal Employment in non-agricultural employment, by sex 1994/2000

\begin{tabular}{|l|l|l|l|}
\hline Region & $\begin{array}{l}\text { Informal } \\
\text { employment as \% of } \\
\text { non-agricultural } \\
\text { employment }\end{array}$ & $\begin{array}{l}\text { Women's informal } \\
\text { employment as \% of } \\
\text { women's non- } \\
\text { agricultural } \\
\text { employment }\end{array}$ & $\begin{array}{l}\text { Men's informal } \\
\text { employment as \% } \\
\text { of men's non- } \\
\text { agricultural } \\
\text { employment }\end{array}$ \\
\hline North Africa & 48 & 43 & 49 \\
\hline Sub-Saharan Africa & 72 & 84 & 63 \\
\hline Latin America & 51 & 58 & 68 \\
\hline Asia & 65 & 65 & 65 \\
\hline
\end{tabular}

Source: ILO (2002) at 19.

Notwithstanding this growth in informal employment and its dominance in much of the developing world, the informal economy has often been viewed as a sphere of the economy that is distinct from the formal sector. There have, of course, been a number of insightful contributions ${ }^{16}$ highlighting the linkages between the formal and informal spheres of the economy. In the policy arena, however, it is often the case that these are seen as separate and unrelated aspects of the economy. GuhaKhasnobis et $a{ }^{17}$ highlight the fact that the formal and informal divide is still very much dominant. They argue that "we need to move beyond formality and informality to make progress in understanding the realities of economic activities in poor countries, and to design policies to benefit the poor."

There are two strands in the literature on the informal sector that do consider the issue of the relationship between the formal and informal. First, there is that concerned with defining the informal sector, which often defines it in relation to formal enterprises. The informal sector is easier to enter, has smaller enterprises using different and more indigenous technologies and is less skilled and regulated than the formal sector. Second, and related to this, the literature has been concerned with the structural relationship of the informal economy in relation to the rest of the economy. In the 1970s Marxists were concerned with whether the informal

16 See, for example, Tokman V "An exploration into the nature of informal-formal sector relationships" (1978).

17 Guha-Khasnobis et al Linking the Formal and Informal Economy (2006). 
economy constituted a reserve army of labour or "petty commodity production". More recently, with the growing interest in micro-entrepreneurship especially among neo-liberal economists, the emphasis has been on issues of regulation in the formal sector and the growth of budding entrepreneurs in the informal economy, supposedly free of the regulatory burden that exists in the formal sector. ${ }^{18}$ We are beginning to see the emergence of a literature exploring these issues of linkages in South Africa.

\subsection{Intra-sectoral relationship between formal and informal economies}

Evidence suggests informal activity is more prolific in some industrial sectors than in others. The presence of a high proportion of informal activity is likely to suggest some form of linkage with the formal equivalent. Drawing on data from Statistics South Africa's national accounts section, Budlender et al ${ }^{19}$ provide estimates of value added in the informal economy and the total economy (Table 2). These estimates confirm the relative importance of the informal economy in trade, construction and community services. The contribution of the informal sector within agriculture is unfortunately unknown as it is included in subsistence agriculture figures provided by the national Department of Agriculture.

Table 2: Contribution of informal economy to value added, 1999 (R million)

\begin{tabular}{|l|l|l|l|}
\hline Industry & Informal & Total & Informal as \% of total \\
\hline Mining & 89 & 44186 & 0.2 \\
\hline Manufacturing & 4782 & 135952 & 3.5 \\
\hline Construction & 3893 & 21263 & 18.3 \\
\hline Trade & 25019 & 95159 & 26.3 \\
\hline Transport & 3311 & 71340 & 4.6 \\
\hline Business services & 8967 & 141928 & 6.3 \\
\hline Community services & 3801 & 21119 & 18.0 \\
\hline
\end{tabular}

Source: Budlender et al (2001).

Using an input-output model supplemented by surveys, Naidoo et al ${ }^{20}$ develop estimates of formal and informal output for the economy. Their estimates show that informal production accounts for a substantial proportion of total production in selected sectors, notably trade, finance and construction (see Table 3 below).

${ }^{18}$ See Maloney "Informality revisited" (2004)

19 Budlender, et al "The Informal Economy" (2001)

${ }^{20}$ Naidoo, et al "Linkages between formal and informal sectors in South Africa" (2004) 
Table 3: Formal and Informal Economy Production

\begin{tabular}{|l|c|c|c|c|l|}
\hline Sector & $\begin{array}{l}\text { Total } \\
\text { production }\end{array}$ & $\begin{array}{l}\text { Total formal } \\
\text { production }\end{array}$ & $\begin{array}{l}\text { Total } \\
\text { informal } \\
\text { production }\end{array}$ & $\begin{array}{l}\text { Informal as } \\
\text { \% of total } \\
\text { production }\end{array}$ & $\begin{array}{l}\text { \% of } \\
\text { inform } \\
\text { al }\end{array}$ \\
\hline Agriculture & 30503 & 27626 & 2878 & 9.4 & 5.7 \\
\hline Mining & 51358 & 51277 & 81 & 0.2 & 0.2 \\
\hline Manufacturing & 236782 & 230380 & 6402 & 2.7 & 12.7 \\
\hline $\begin{array}{l}\text { Electricity, } \\
\text { Gas, Water }\end{array}$ & 26551 & 26551 & 0 & 0.0 & 0.0 \\
\hline Construction & 35597 & 27839 & 7758 & 21.8 & 15.4 \\
\hline Trade & 100056 & 83460 & 16596 & 16.6 & 33.0 \\
\hline Transport & 46695 & 43659 & 3037 & 6.5 & 6.0 \\
\hline Finance & 71045 & 60605 & 10440 & 14.7 & 20.7 \\
\hline Other & 32844 & 29689 & 3155 & 9.6 & 6.3 \\
\hline Total & 631431 & 581084 & 50347 & 8.0 & 100.0 \\
\hline
\end{tabular}

Source: Naidoo et al (2004)

Skinner ${ }^{21}$ reports on a comprehensive survey of informal enterprises in the greater Durban area, where some 507 detailed surveys with informal workers were conducted. Her study provides some useful indicators of forward and backward linkages in the informal economy. Figure 1 below shows sourcing of raw material for informal enterprises in the Durban area.

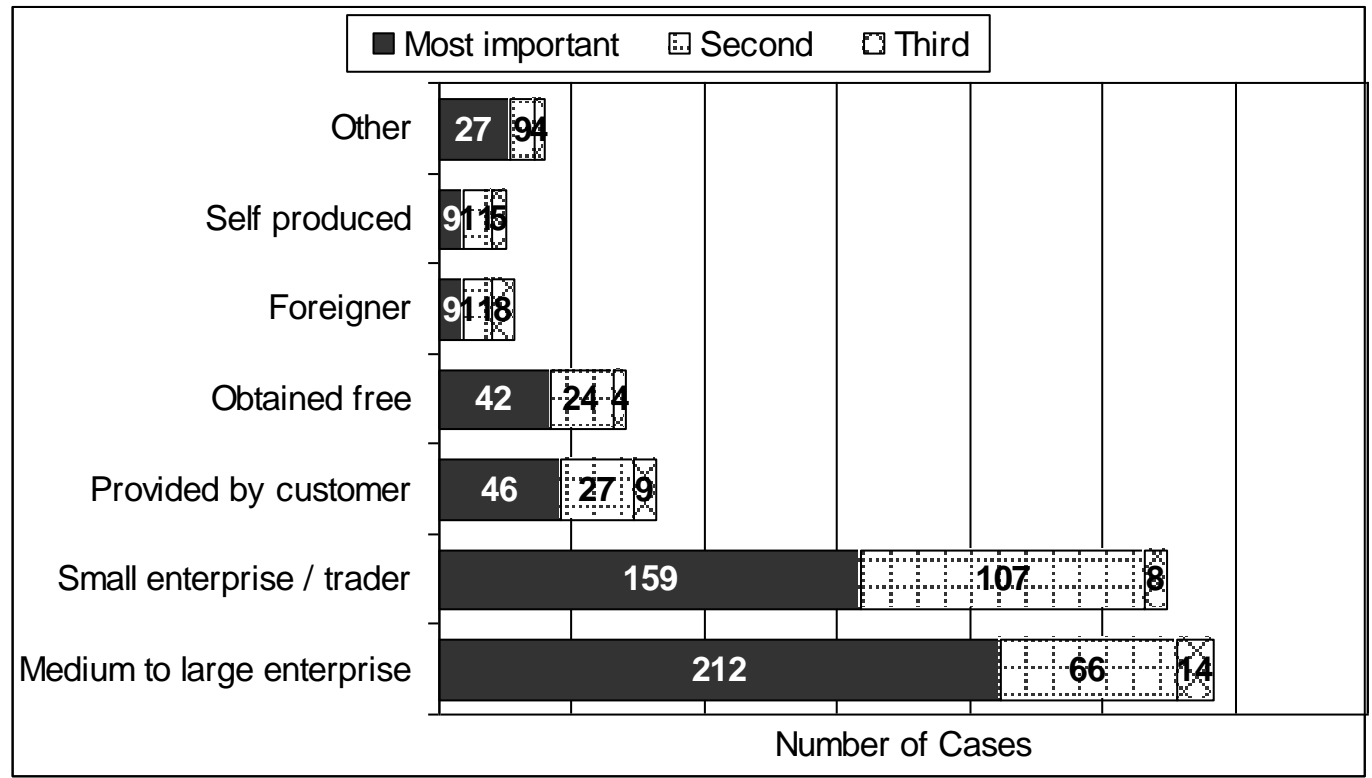

Figure 1: Source of supply, $\mathbf{n = 5 0 3}$ (source: Skinner, 2005).

${ }^{21}$ Skinner "Constraints to growth and employment in Durban" (2005). 
The most frequently cited source of supply is medium to large (formal) enterprises, with six in every ten enterprise owners identifying this as a source. This suggests quite strong forward linkages into the formal economy. The second most cited source was a small enterprise or trader, with over five in every ten respondents identifying this as a source. A portion of these are also likely to be in the formal economy. It is interesting to note the role of foreign-linked supply networks in the informal economy. One in twenty respondents stated they sourced their goods from a foreigner.

As is to be expected, there are sectoral differences in these linkages. Table 4 below shows that certain informal activities are more strongly linked into the formal economy than others. Trade sectors (apparel, spaza shops and shebeens) tended to source their goods in medium and large shops. Just over half of those in the construction sector sourced supplies from medium and large shops. The responses from those working in traditional medicine indicated that a number of formal shops and foreigners were involved in supply. There are also more formal shops involved in supply of crafts than would be expected in a segment of the economy that is often considered to be entirely informal. With regard to apparel, a group of those interviewed are likely to be dressmakers as their supplies were provided by their customers.

Table 4: Source of supply by percentage in sector, $n=503$ (multiple responses recorded)

\begin{tabular}{|l|c|c|c|c|c|c|c|}
\hline & $\begin{array}{l}\text { Medium/ } \\
\text { large } \\
\text { shop }\end{array}$ & $\begin{array}{l}\text { Small } \\
\text { shop/ } \\
\text { trader }\end{array}$ & $\begin{array}{l}\text { Provided } \\
\text { by } \\
\text { customer }\end{array}$ & Foreign & $\begin{array}{l}\text { Obtained } \\
\text { free }\end{array}$ & $\begin{array}{l}\text { Self- } \\
\text { produced }\end{array}$ & Other \\
\hline Apparel & 61 & 70 & 40 & 4 & 1 & 2 & 4 \\
\hline Craft & 43 & 73 & 1 & 9 & 13 & 5 & 5 \\
\hline $\begin{array}{l}\text { Traditional } \\
\text { medicine }\end{array}$ & 19 & 54 & 0 & 18 & 69 & 15 & 25 \\
\hline Spaza shops & 79 & 48 & 0 & 0 & 0 & 2 & 2 \\
\hline Construction & 56 & 41 & 51 & 0 & 5 & 0 & 3 \\
\hline Metal work & 79 & 37 & 30 & 2 & 0 & 0 & 5 \\
\hline Shebeens & 85 & 46 & 0 & 0 & 0 & 2 & 0 \\
\hline Crèches & 67 & 36 & 15 & 3 & 5 & 13 & 15 \\
\hline Hairdressing & 66 & 51 & 22 & 5 & 0 & 0 & 7 \\
\hline N & 292 & 274 & 82 & 28 & 70 & 25 & 40 \\
\hline
\end{tabular}

Source: Skinner (2005)

The overwhelming majority of respondents - 495 or $98.4 \%$ of those interviewed sold their goods and services to private individuals or households. The forward linkages to other informal enterprises as well as the formal economy are thus not 
strong. Only 26 respondents (5.2\%) said they sold to other informal enterprises. Just 15 enterprise owners (3\%) reported that they sold to formal enterprises and 11 $(2.2 \%)$ said they sold to "middlemen" or agents. There also seems to be very little exporting, with only three respondents saying they sold to foreign businesses. There may be an undercount on this in certain sectors.

Case study evidence indicates that there are multiple forward and backward linkages between formal and informal activities. For example, Ince's work on informal clothing manufacturing in a residential area in Durban demonstrated not only that manufacturers source their inputs in the formal economy, but that garments often end up in formal retail stores. ${ }^{22}$ Also Witt's work on informal fruit and vegetable distribution demonstrates multiple linkages. ${ }^{23}$

Valodia et $a l^{24}$ examine economic and competitive relationships between the formal and informal economy. They explore whether pricing and related economic behaviour is shaped by considerations in the formal economy. Based on surveys conducted in informal markets in the Durban area, they find some evidence that informal street vendors are well-informed of prices in the formal economy and that their price-setting behaviour is shaped to some extent by the formal economy. Informal vendors competed with the formal retailers by offering similar products for sale, but in smaller packages and along convenient transport nodes in the city. In other words, there appears to be relatively higher levels of interaction in decisionmaking between formal and informal retailers.

\subsection{Churning between formal and informal labour markets}

The panel component of the Labour Force Survey (LFS) allows us to explore dynamics in the labour market. The sampling design of the LFS, which is conducted bi-annually in March (previously February) and September allows for $80 \%$ of the sampling in each wave to remain in the sample. Thus, households remain in the sample over a consecutive number of surveys.

We explore the labour market dynamics in these households beginning in February 2002 for five waves of the LFS ending in March 2004. Matching the individuals in these households over the period, we are able to get some indication of the extent to which workers move between employment and unemployment, and when employed between different segments of the economy, such as formal and informal. ${ }^{25}$ In total we were able to match 5587 individuals over the period. Table gives a broad overview of how the status of these workers changed over the period.

\footnotetext{
22 Ince "Nature of informal clothing manufacturing in a residential area" (2003)

23 Witt "Fresh produce distribution networks in the Durban metropolitan area" (2003)

${ }^{24}$ Valodia, et al "Exploring economic behavior in South Africa's informal economy" (2007)

25 Note that the panel component of the LFS allows us to track households not individuals over the five waves of the survey. We have examined the sex and age profiles of workers in these households to confirm that the individuals remain in the panel. We have thus removed from the panel all households where the individuals inside the household may have changed (through, for example, migration).
} 
The data shows that there is a surprising level of churning within the labour market, with the status of more than half of the workers having changed at least once over the period February 2002 to March 2004. As is to be expected, for those workers whose status remained unchanged, most tended to be employed in the formal sector, or remained economically inactive. Only $1.3 \%$ of the 5587 workers that remained in the panel continued to work in the informal economy over the period under consideration.

Table 5: Labour market status, February 2002 to March 2004, n=5 587

\begin{tabular}{|l|l|l|}
\hline Type of Worker & Frequency & Percent \\
\hline Remained in the formal economy & 1,175 & 21.0 \\
\hline Remained economic inactive & 1,077 & 19.3 \\
\hline $\begin{array}{l}\text { Remained in commercial } \\
\text { agriculture }\end{array}$ & 99 & 1.8 \\
\hline Remained a domestic worker & 89 & 1.6 \\
\hline Remained unemployed & 74 & 1.3 \\
\hline Remained an informal worker & 71 & 1.3 \\
\hline Worker status changed & 3,002 & 53.7 \\
\hline & 5,587 & 100.0 \\
\hline
\end{tabular}

(Source: Authors' calculations from various LFSs)

In Table 6 below we remove from the panel all workers who did not engage in informal economy activities over the period; i.e., we retain only workers who have been engaged in informal economy activities for at least one period. This reduces the number of workers from 5587 to 1009 . Again we see a surprising level of churning occurring, with only $7 \%$ of workers remaining as informal workers over the entire period.

Table 6: Labour market status of informal economy workers, February 2002 to March 2004, n=1 009

\begin{tabular}{|l|l|l|}
\hline Type of Worker & Frequency & Percent \\
\hline Informal for 5 periods & 71 & 7.0 \\
\hline Informal for 4 periods & 88 & 8.7 \\
\hline Informal for 3 periods & 106 & 10.5 \\
\hline Informal for 2 periods & 202 & 20.0 \\
\hline Informal for 1 period & 542 & 53.7 \\
\hline & 1,009 & 100.0 \\
\hline
\end{tabular}

(Source: Authors' calculations from various LFSs) 
Table 7 shows the movement of workers that were employed in the informal economy in any one period over the panel. As is to be expected, a large number of workers moved between the informal economy and being unemployed or economically inactive. A significant proportion of workers (18.3\%) moved between formal and informal employment.

\section{Table 7: Shifts between informal work and other Labour Market Status}

\begin{tabular}{|l|l|l|}
\hline Type of Change & Frequency & Percent \\
\hline $\begin{array}{l}\text { Informal and unemployed and not } \\
\text { economically active }\end{array}$ & 191 & 18.9 \\
\hline $\begin{array}{l}\text { Informal and not economically } \\
\text { active }\end{array}$ & 190 & 18.8 \\
\hline Informal and formal & 185 & 18.3 \\
\hline Informal, formal and unemployed & 77 & 7.6 \\
\hline $\begin{array}{l}\text { Informal, formal and not } \\
\text { economically active }\end{array}$ & 73 & 7.2 \\
\hline Remained in informal & 71 & 7.0 \\
\hline Informal and unemployed & 60 & 5.9 \\
\hline $\begin{array}{l}\text { Informal, formal, unemployed and } \\
\text { not economically active }\end{array}$ & 44 & 4.4 \\
\hline Other & 118 & 11.7 \\
\hline & 1,009 & 100.0 \\
\hline
\end{tabular}

(Source: Authors' calculations from various LFSs)

If we reduce the period under consideration to the six months between September 2003 and March 2004, we still find fairly high levels of churning in the labour market. Of those individuals recorded as informal workers in September 2003, in March 2004 44.5\% reported working in the informal economy, 17.3\% reported working in the formal economy, $11.4 \%$ reported being unemployed and $23.7 \%$ reported being not economically active. Of individuals recorded as formal workers in September 2003, in March 2004 3.4\% reported working in the informal economy.

We are able to exploit income data in the LFS to explore some of the income dynamics related to movements between the formal and informal sectors. In particular, we explore below the shifts of the 185 movements between formal and informal reported in Table 7 above. Given that we are dealing with a 5-period panel there are a large number of formal and informal movements that are possible. In order to keep the analysis manageable, we focus only on some movements.

Table 8 below summarises the movements that we will explore. The first, FFFFI, which occurs 39 times in the panel, shows workers that reported being in formal jobs over the LFSs for February 2002 to September 2003 (i.e., 4 surveys) and then shifted to an informal job in the last period of the panel (March 2004). Similarly, the 
second, FFFIF, which occurs 14 times, shows workers in formal jobs over the initial 3 surveys, moving into an informal job in the fourth period (September 2003) but then moving back into a formal job in March 2004.

Table 8: Movements between formal and informal jobs, 2001-2004

\begin{tabular}{|l|l|}
\hline Movements between formal and informal economy & Number of occurrences \\
\hline FFFFI & 39 \\
\hline FFFIF & 14 \\
\hline FFIFF & 20 \\
\hline IFFFF & 19 \\
\hline Other & 93 \\
\hline Total & 185 \\
\hline
\end{tabular}

(Source: Authors' calculations from various LFSs)

Using the LFS income bands ${ }^{26}$ and excluding non-responses, we observed very little change in FFFFI workers incomes over the fourth and fifth periods of the panel, when the worker shifts from formal to informal employment. Similarly, for IFFFF workers there was very little change in incomes over the first and second periods when the worker moves from informal to a formal employment. Using the median of income categories, we calculated that workers moving from formal to informal lose R236 on average while workers moving from informal to formal gain R424 on average. Although not reported in the article, shifts in incomes are relatively minor for the other combinations of formal and informal work over the five periods under consideration.

Both in terms of the formal and informal classification, and in terms of the incomes reported, the data suggests two important characteristics of formalinformal linkages. First, at the low end of the labour market, in what we have called low-waged work, the South African data suggests high levels of churning between formal and informal employment over a relatively short period of time. This suggests that low-waged workers are unlikely to benefit significantly from shifting from informal to formal employment, and vice-versa. Second, unlike the case in Latin America where Maloney ${ }^{27}$ and others have argued that workers choose to move into the informal sector to escape onerous legislative requirements, there are two arguments that appear to counter this free-choice view. On the one hand the movements occur in both directions, not just formal to informal which one would expect if the free-choice view dominates. On the other hand, as the gross incomes above suggest, there seems to be very little, if any, economic benefit associated with movements from formal to informal employment.

26 The income bands are as follows: $1=$ None, $2=\mathrm{R} 1-\mathrm{R} 200,3=\mathrm{R} 201-500,4=\mathrm{R} 501-1000,5=\mathrm{R} 1001-$ $1500,6=\mathrm{R} 1501-2500,7=\mathrm{R} 2501-3500$, 8=R3501-4500, $9=\mathrm{R} 4501-6000,10=\mathrm{R} 6001-8000,11=\mathrm{R} 8001-$ $11000,12=\mathrm{R} 11001-16000, \mathrm{R} 13=16001-30000, \mathrm{R} 14=30000+$.

27 Maloney (2004). 


\subsection{Intra-household linkages between the formal and informal worker}

Another possible linkage between work in the formal and the informal sector can occur within the household. Using the KwaZulu-Natal Income Dynamics Survey (KIDS), ${ }^{28}$ Lebani and Valodia ${ }^{29}$ explore employment transitions in households between 1993 and 1998. They find evidence of an intra-household link between self-employment activities and formal economy workers. This association suggests that there is a transfer of human and financial capital by the formally employed to self-employment activities, since it is the households that have some form of regular income that are mostly involved in self-employment initiatives. In short, households with access to a formal job are more likely to have access to resources for another member of the household to earn an income in the informal sector. Similarly, Webster states that "the modern sector depends on the informal and the majority of households combine work in the two sectors" 30 .

Our analysis of the March 2004 LFS shows that, in South Africa, 5891135 households have at least one formal worker and 1639783 households have at least one informal worker. ${ }^{31}$ However, relatively few households -326275 or $2.5 \%$ of households - accommodate at least one formal and one informal worker. Of all households, just over a quarter million (254 672) are composed of one formal and one informal worker. Households with both a formal and informal worker represent an interesting focus, since these are effectively a centre for the continuum between households with exclusively formal and informal workers.

What is the nature of these households? Has the household structure come about by choice or because of growing informalisation of the labour market? What are the income and poverty characteristics of these households?

Ninety-four percent of single formal-single informal worker households do not accommodate another type of worker (that is, an agricultural or domestic worker). Thirty-eight percent of these households have no other member of working age. However, $38.6 \%$ accommodate at least one economically inactive person, $10.2 \%$ accommodate both economically inactive and unemployed members, and $7.5 \%$ accommodate at least one unemployed member. The high proportion of households with dependants supports Webster's claim, citing work by Mosoetsa, that many households attract members in need of support. ${ }^{32}$

Table 9 below shows that single formal-single informal households are more likely to be located in urban areas, have a larger household size than the average South African household and, proportionately, coloured and white households are over-represented among these households.

\footnotetext{
28 See www.ukzn.ac.za/csds for details of the KIDS data.

${ }^{29}$ Lebani and Valodia "The dynamics of employment and poverty in South Africa" (2005).

30 Webster "The dual economy" (2004).

${ }^{31}$ At the worker level the ratio of formal to informal workers is 1: 0.23 (7 827 251: 1833 612); the ratio at household level is marginally less, i.e. 1: 0.27.

32 Webster (2004).
} 
Table 9: Single formal-single informal households

\begin{tabular}{|l|l|l|}
\hline & All households (\%) & $\begin{array}{l}\text { Single formal-single informal } \\
\text { households (\%) }\end{array}$ \\
\hline Urban & 60.5 & 69.3 \\
\hline Black & 77.8 & 69.3 \\
\hline Coloured & 7.9 & 11.5 \\
\hline Indian & 2.5 & 1.8 \\
\hline White & 11.8 & 17.3 \\
\hline N in household (mean) & 3.6 & 4.7 \\
\hline
\end{tabular}

(Source: authors calculations from LFS)

Shifting to the worker level, some interesting associations between the formal and informal workers in the same household become evident. Table 10 shows that there appears to be a strong association between category of occupation of formal and informal workers.

Table 10: Occupation of formal worker by occupation of informal worker

\begin{tabular}{|l|l|l|l|l|l|l|l|l|l|}
\hline & \multicolumn{2}{|l|}{ Occupation of formal worker } \\
\hline $\begin{array}{l}\text { Occupa- } \\
\text { tion of } \\
\text { informal } \\
\text { worker }\end{array}$ & $\begin{array}{l}\text { Mana- } \\
\text { ger }\end{array}$ & $\begin{array}{l}\text { Profess- } \\
\text { ional }\end{array}$ & $\begin{array}{l}\text { Techni } \\
\text {-cian }\end{array}$ & Clerk & $\begin{array}{l}\text { Service } \\
\text { worker }\end{array}$ & $\begin{array}{l}\text { Craft } \\
\text { worker }\end{array}$ & $\begin{array}{l}\text { Opera- } \\
\text { tor }\end{array}$ & $\begin{array}{l}\text { Elemen- } \\
\text { tary } \\
\text { occupa- } \\
\text { tion }\end{array}$ & Total \\
\hline Manager & 7.2 & 6.8 & 11.6 & 15.4 & 0.6 & 10.0 & 0.0 & 2.5 & 6.3 \\
\hline $\begin{array}{l}\text { Profess- } \\
\text { ional }\end{array}$ & 30.7 & 31.9 & 2.2 & 1.5 & 0.5 & 0.0 & 2.5 & 0.0 & 4.0 \\
\hline $\begin{array}{l}\text { Techni- } \\
\text { cian }\end{array}$ & 39.1 & 32.9 & 14.7 & 9.1 & 10.3 & 5.5 & 8.0 & 5.7 & 11.3 \\
\hline Clerk & 0.0 & 0.0 & 0.0 & 1.1 & 2.2 & 0.0 & 2.9 & 11.4 & 3.7 \\
\hline $\begin{array}{l}\text { Service } \\
\text { worker }\end{array}$ & 4.4 & 12.3 & 13.1 & 13.2 & 22.0 & 19.1 & 19.9 & 11.7 & 15.1 \\
\hline $\begin{array}{l}\text { Craft } \\
\text { worker }\end{array}$ & 8.9 & 4.4 & 24.0 & 33.0 & 22.8 & 16.5 & 26.4 & 18.8 & 21.1 \\
\hline Operator & 0.0 & 0.0 & 3.0 & 2.3 & 11.5 & 6.6 & 7.0 & 5.9 & 5.5 \\
\hline $\begin{array}{l}\text { Elemen- } \\
\text { tary } \\
\text { occupa- } \\
\text { tion }\end{array}$ & 9.8 & 11.7 & 31.4 & 24.5 & 30.1 & 42.5 & 33.2 & 43.9 & 32.9 \\
\hline N & 9776 & 16453 & 34771 & 34 & 40704 & 30377 & 21592 & 66446 & 254 \\
\hline
\end{tabular}


For example, when the formal worker is a manager $(n=9,776), 30 \%$ of the cohabiting informal workers were professionals and 39\% were in technical occupations. Fewer than $10 \%$ of the informal workers paired with a formal manager reported an elementary occupation. Similar trends are observed for professional formal workers. As the category of occupation becomes less skilled the proportion of elementary informal workers paired with a formal worker increases. For example, $31.4 \%$ of formal technicians are paired with an elementary informal worker. And at the lowest end of the scale, when the formal worker reported an elementary occupation $(n=66,446), 44 \%$ of cohabiting informal workers were in elementary occupations, $14 \%$ craft workers, $11 \%$ service, $11 \%$ clerks, less than $6 \%$ technical, and only $2.5 \%$ were managers. There is a distinct distribution by gender for formal and informal workers (see Table 11). When the formal worker is male, $77.8 \%$ of the cohabiting informal workers are female. Similarly, when the formal worker is female, $81.9 \%$ of informal workers are male.

Table 11: Gender of formal worker by gender of informal worker

\begin{tabular}{|l|l|l|}
\hline & Gender of formal worker \\
\hline Gender of informal worker & Male & Female \\
\hline Male & 22.2 & 81.9 \\
\hline Female & 77.8 & 18.8 \\
\hline $\mathrm{N}$ & 143327 & 111345 \\
\hline
\end{tabular}

Table 12 shows that the cohabiting male and female workers are likely to be in a marital partnership. When the formal worker is married or living together, $90.3 \%$ of the informal workers report being married or living together. A significantly lower percentage of formal workers who have never married cohabit with an informal worker who is married (31.5\%).

Table 12: Marital status of formal and informal worker

\begin{tabular}{|l|l|l|l|l|}
\hline & \multicolumn{3}{|l|}{ Marital status of formal worker } \\
\hline $\begin{array}{l}\text { Marital status of } \\
\text { informal worker }\end{array}$ & $\begin{array}{l}\text { Married/ } \\
\text { living } \\
\text { together }\end{array}$ & Widowed & $\begin{array}{l}\text { Divorced/ } \\
\text { separated }\end{array}$ & Never married \\
\hline $\begin{array}{l}\text { Married/ living } \\
\text { together }\end{array}$ & 90.3 & 25.4 & 19.4 & 31.5 \\
\hline Widowed & 1.0 & 0.0 & 0.0 & 6.8 \\
\hline Divorced/ separated & 0.0 & 0.0 & 25.7 & 4.9 \\
\hline Never married & 8.7 & 74.6 & 55.0 & 56.8 \\
\hline $\mathrm{N}$ & 175061 & 4477 & 4557 & 70577 \\
\hline
\end{tabular}

Where the female formal worker is paired with an informal female worker it would be interesting to know whether the relationship is that of mother and 
daughter. Unfortunately the LFS does not allow us to establish the relationship between individuals (other than partnerships). However, it is possible to infer a relationship by looking at age. Table 13 shows that the average age of cohabiting formal and informal workers is 41.6 and 41.5 years respectively. The average age of cohabiting formal and informal female workers is 34.5 and 43.5 years respectively. If this age difference indeed reflects a mother-daughter relationship, the older woman is apparently the informal worker. However, the relationship can work in both directions, as demonstrated in Table 13. This table shows that high proportions of older formal women cohabit with young informal women and high proportions of younger formal women cohabit with older informal women (although on average informal women workers are older).

Table 13: Age of formal and informal worker in households with two female workers

\begin{tabular}{|l|l|l|l|l|}
\hline & \multicolumn{4}{|l|}{ Age of female formal worker } \\
\hline $\begin{array}{l}\text { Age of female } \\
\text { informal worker }\end{array}$ & $20-29$ yrs & $30-39$ yrs & $40-49$ yrs & $50-59$ yrs \\
\hline $15-19$ yrs & 0.0 & 0.0 & 24.5 & 0.0 \\
\hline $20-29$ yrs & 0.0 & 7.4 & 48.3 & 50.1 \\
\hline $30-39$ yrs & 4.7 & 4.1 & 0.0 & 35.7 \\
\hline $40-49$ yrs & 50.2 & 45.1 & 14.9 & 14.2 \\
\hline $50-59$ yrs & 13.6 & 28.7 & 0.0 & 0.0 \\
\hline $60-69$ yrs & 28.3 & 14.6 & 12.4 & 0.0 \\
\hline $70+$ yrs & 3.2 & 0.0 & 0.0 & 0.0 \\
\hline $\mathrm{N}$ & 9002 & 4074 & 3654 & 3453 \\
\hline
\end{tabular}

Table 14 (see page 17 below) shows that there is a significant positive association between education levels of cohabiting formal and informal workers. Of formal workers with no education, $50.3 \%$ cohabit with an informal worker with no education and $44.4 \%$ with an informal worker with primary education only. In contrast, of formal workers with post-matric, $41.0 \%$ cohabit with an informal worker with post-matric and $26.3 \%$ with an informal worker with matric.

Further, there is a significant positive association between income of formal and informal worker cohabiting. In the case of formal workers earning R1-200, 81.6\% of the informal workers cohabiting earn R1 000 or less. In contrast, of formal workers earning R11 001-30 000+, just 6.2\% of informal workers cohabiting earn R1 000 or less. However, as is evident from

Table 15 (see page 17 below), some informal workers earn more than their formal counterparts. For example, when a formal worker reports earning R1-200, almost $70 \%$ of their informal partners earn over R200. 
Table 14: Education levels in households, formal: informal workers

\begin{tabular}{|l|l|l|l|l|l|}
\hline & \multicolumn{2}{|l}{ Education of formal worker } \\
\hline $\begin{array}{l}\text { Education } \\
\text { of informal } \\
\text { worker }\end{array}$ & No education & Primary & Secondary & Matric & Post-matric \\
\hline $\begin{array}{l}\text { No } \\
\text { education }\end{array}$ & 50.3 & 14.3 & 3.9 & 5.7 & 2.7 \\
\hline Primary & 44.4 & 44.5 & 23.8 & 14.0 & 6.6 \\
\hline Secondary & 0.0 & 29.7 & 52.2 & 40.1 & 23.3 \\
\hline Matric & 0.0 & 10.4 & 18.6 & 32.4 & 26.3 \\
\hline Post-matric & 5.3 & 1.2 & 1.4 & 7.9 & 41.0 \\
\hline $\mathrm{N}$ & 5,078 & 45,187 & 71,641 & 68,974 & 60,841 \\
\hline
\end{tabular}

Table 15: Incomes, formal: informal workers

\begin{tabular}{|l|l|l|l|l|l|l|l|l|}
\hline \multicolumn{7}{|l|}{ Income of formal worker } \\
\hline $\begin{array}{l}\text { Income of } \\
\text { informal } \\
\text { worker }\end{array}$ & $\begin{array}{l}\text { R1- } \\
200\end{array}$ & $\begin{array}{l}\text { R201- } \\
500\end{array}$ & $\begin{array}{l}\text { R501- } \\
1000\end{array}$ & $\begin{array}{l}\text { R1 001- } \\
1500\end{array}$ & $\begin{array}{l}\text { R1 501- } \\
2500\end{array}$ & $\begin{array}{l}\text { R2 501- } \\
4500\end{array}$ & $\begin{array}{l}\text { R4 501 - } \\
11000\end{array}$ & $\begin{array}{l}\text { R11 001 } \\
-30\end{array}$ \\
\hline None & 0.0 & 0.0 & 4.3 & 1.3 & 0.8 & 0.0 & 0.0 & 0.0 \\
\hline R1-200 & 31.2 & 31.6 & 9.7 & 12.6 & 8.8 & 14.4 & 3.7 & 0.6 \\
\hline R201-500 & 36.2 & 39.0 & 32.7 & 17.0 & 27.2 & 21.6 & 9.7 & 2.8 \\
\hline $\begin{array}{l}\text { R501- } \\
1000\end{array}$ & 14.2 & 23.5 & 21.2 & 26.4 & 25.3 & 24.3 & 9.0 & 2.8 \\
\hline $\begin{array}{l}\text { R1 001- } \\
1500\end{array}$ & 0.0 & 2.1 & 16.8 & 14.1 & 14.4 & 7.6 & 9.3 & 0.0 \\
\hline $\begin{array}{l}\text { R1 501- } \\
2500\end{array}$ & 18.4 & 3.9 & 2.3 & 23.2 & 13.8 & 13.9 & 10.6 & 14.4 \\
\hline $\begin{array}{l}\text { R2 501- } \\
4500\end{array}$ & 0.0 & 0.0 & 8.2 & 4.6 & 3.4 & 10.5 & 12.5 & 19.0 \\
\hline $\begin{array}{l}\text { R4 501- } \\
11000\end{array}$ & 0.0 & 0.0 & 4.9 & 0.7 & 3.9 & 5.4 & 20.4 & 51.2 \\
\hline $\begin{array}{l}\text { R11 001- } \\
30000\end{array}$ & 0.0 & 0.0 & 0.0 & 0.0 & 2.4 & 2.3 & 24.8 & 9.1 \\
\hline N & 3,283 & 16,293 & 45,621 & 34,421 & 37,892 & 36,022 & 42,075 & 9,750 \\
\hline
\end{tabular}

\section{3 "Informal" formal labour and labour brokering}


A final set of trends, representing a less explicit linkage between formal and informal, is the growing informalisation of the formal and increasing use of labour brokering within the South African economy. Devey et $a^{33}$ show that many workers classified as formal workers have employment characteristics that are consistent with informal work. There is also significant evidence from micro-level studies which highlights the growing informalisation of previously formal work. Kenny ${ }^{34}$ in her analysis of the retail sector not only demonstrates that casual and subcontracted labour constitutes up to $65 \%$ of total employment, but highlights how core tasks like shelf-packing are increasingly done by employees of labour brokers, contracted by suppliers. Skinner and Valodia's analysis of COFESA ${ }^{35}$ revealed that COFESA firms no longer had to adhere to collective agreements on minimum wages or contribute to any of the benefit or training schemes. In the workplace, other than changes in labour conditions, everything else remained the same. Skinner and Valodia demonstrated how by the end of 2000 COFESA estimated that this had resulted in the creation of over 700000 independent contractors. Similarly, almost all interviewees in Theron and Godfrey's ${ }^{36}$ study of stakeholders from numerous industries - retail, mining, manufacturing (food, clothing, metal and engineering) catering and accommodation, construction and transport - reported an increase in the use of labour brokers and employment agencies.

The legislative loophole in the Labour Relations Act (LRA) that COFESA was using was subsequently closed. ${ }^{37}$ It is unclear whether the processes COFESA set in place have been reversed.

\section{DISCUSSION}

The articulation of the "first" and "second" economy conceptualisation of South Africa by the Presidency coincided, we would argue, with a refocusing of economic policy in South Africa. This conceptualisation tacitly acknowledges the failure of the trickle-down economic growth policies so central to the post-1996 "GEAR"38 era

\footnotetext{
33 Devey et al "Definitions, data and the informal economy in South Africa" (2006).

${ }^{34}$ Kenny "Militant divisions, collective possibilities" (2005).

35 Skinner and Valodia "Labour market policy, flexibility and the future of labour relations" (2002). COFESA (the Confederation of Employers South Africa) is a labour consultancy that assists companies to restructure their workforces, to change employees to independent contractors and outsource production to them. COFESA members are involved in many different sectors, notably footwear and clothing manufacturing and also food, farming, transport, construction and engineering.

36 Theron and Godfrey "Protecting workers on the periphery" (2000).

37 The labour courts have, in a growing number of cases, ruled that the objective status of an employee cannot be changed by contractual formalities, that an employer and employee cannot "contract out" of the protection provided by the LRA and that the court should have regard to the true nature of an employment relationship rather than the terms used to describe it: see, in particular, Building Bargaining Council (Southern \& Eastern Cape) v Melmons Cabinets CC \& another [2001] 3 BLLR 329 (LC) and Denel (Pty) Ltd v Gerber [2005] 9 BLLR 849 (LAC): - Editor.

38 The reference is to the government's "Growth Employment and Redistribution" policy, introduced in 1996: for concise comment see, e.g., Goldberg M "Small enterprises, the Labour Relations Act and
} 
which inform much of government's more recent emphasis on poverty alleviation. However, the dualism suggested by arguments about a "structural" break between the first and second economy allows government to argue that its economic policies have been successful for the first economy and, as a result of these successes, government is now able to address issues of poverty and unemployment in the second economy. Yet, for all its claimed successes in stabilising South Africa's macroeconomic situation after 1994, promoting black economic empowerment and re-orienting the budget to meet some social objectives, it is accepted even in government that its major failing has been its inability to address South Africa's unemployment situation and, related to this, the high levels of poverty among segments of the population.

At the policy level a clear understanding of the linkages between the formal and the informal economy is critical for the development of good policy. At one level, government's recent preoccupation with the "second economy" has undoubtedly raised the profile of the unemployed and those operating in the informal economy. This is a positive development. However, the concept is not useful for understanding the history and current challenges facing the economy. We have provided evidence that the so-called "first" and second economies are in fact linked. Further, large numbers of workers in South Africa are employed in low-waged work. While the extent of low-waged work is very high in jobs presently classified as informal, large sections of the formal economy are also characterised by low-waged employment. Our analysis of the LFS panel data suggests that there is a surprisingly high level of churning in the labour market, with high levels of movement between formal and informal jobs. The data suggests that these movements occur primarily in the lowwaged segment of the labour market, and incomes do appear to rise or fall as workers move between formal and informal jobs. At the household level we find a bifurcated relationship - households with access to high-income employment in the formal economy seem more able to earn high incomes in the informal economy, and vice versa. What then might be the implications of our findings for research on poverty and the development of policy?

\subsection{Focus on segmented labour markets for employment generation strategies}

Research by Budlender et $a l^{39}$, Naidoo et $a l^{40}$ and Skinner ${ }^{41}$, described above, suggests informal workers are more active in selected industrial sectors - notably trade, construction, community services and finance sectors. This distribution is likely primarily because the informal worker has relatively easy access to an unregulated market in these sectors. This sectoral concentration could be used to

collective bargaining in South Africa" (1997) 1 LDD 83 at 86-87; Gostner K and Joffe A "Negotiating the future: Labour's role in NEDLAC" (1998) 2 LDD 131 at 141 - Editor.

39 Budlender et al (2001).

40 Naidoo, van Aart and Ligthelm, (2004).

${ }^{41}$ Skinner (2005). 
identify opportunities and constraints for employment creation. The findings call to mind Ben Fine's ${ }^{42}$ position on segmented labour markets:

"Hopefully, even this cursory examination of the more general literature on South African labour markets, as well as of the shifting reproduction of the mining labour market, suffices to demonstrate that labour market structures are the product of underlying socio-economic factors, and that the labour markets are structured differently from one another whilst sharing some determinants in common. The specific features of the South African mining labour market is blatant evidence of such a conclusion; it is a market that is entirely different from that of domestic servants or agricultural workers, whatever wages and conditions are attached to them all."

Fine goes on to caution:

"Considerable analytical care needs to be taken in identifying and explaining labour market structures, especially in distinguishing them from differentiation as equality in outcomes. ... that each labour market segment is structured differently. The means vary by which each is created, reproduced and has effects".

Altman and Mayer ${ }^{43}$ have identified construction, social services and food sectors as having significant potential for employment growth in South Africa. These authors propose that "distinct industrial strategies that redress demand and supply constraints and ensure that policy imperatives such as black economic empowerment are realised" and "sustained and credible expenditure" are necessary to achieve employment growth. Like Fine, they suggest a detailed analysis of the industries in question before specific policy is developed and implemented. And although there is apparently less interaction between informal workers and the global markets (in the context of exports) relative to the formal economy, a sectoral strategy would require careful consideration of global relationships. As Rodgers observes:

"Yet numerous pitfalls await any attempt at formulating appropriate policy toward structural fluctuations in today's global economy". ${ }^{44}$

\subsection{Use the decent work agenda as a lens to identify and stabilise insecure employment}

The existence of churning within and between the formal and informal economies suggest that there may be some security of employment over a short period but that over a longer period informal work is unstable and precarious. This finding is borne out by research of Ligthelm ${ }^{45}$ who argues that just 10-15\% of informal entrepreneurs have the skills to expand their business. This, along with evidence of increased labour brokering, demonstrates high levels of insecure employment.

\footnotetext{
${ }^{42}$ Fine (1998).

${ }^{43}$ Altman and Meyer "Sectoral strategies for employment creation" (2003) at 21.

44 Phelps et al Structural Slump (1994).

${ }^{45}$ Ligthelm "A targeted approach to informal business development" (2008).
} 
The newer work-based definition of informal work resonates with the decent work framework developed by the International Labour Organisation (ILO). ${ }^{46}$ The decent work agenda stems from concerns that the labour market will increasingly be populated by low productivity survivalist jobs, forced labour, or employment guarantees without productive outcome. ${ }^{47}$ The decent work agenda includes access to productive employment for all, security of work and income and respect for core rights at work. ${ }^{48}$ This agenda would marry well with policy focused on addressing insecure employment.

There is evidence that the decent work agenda has gained a strong foothold in South African political rhetoric. Thus, President Jacob Zuma is reported that have stated that "[t]he creation and retention of decent jobs will be the primary focus of all economic policies of the ANC government". ${ }^{49}$ Decent work also features in the Presidency's second economy framework, which states that "[n]ew work, decent work is likely to come mainly from growth in the more developed, formal, core economy: including the more formal end of the SME" ${ }^{50}$ Decent work is also a central pillar of COSATU's policy agenda.

In the second economy strategy, one of the interventions proposed for the most marginalised is to massively expand public employment, including a form of minimum employment guarantee. ${ }^{51}$ This is laudable as a temporary solution. However, Booth ${ }^{52}$ has criticised earlier formulations of public works programmes because of poor job standards; and there is a question as to whether newer manifestations either qualify as decent work or are leading to sustained (secure) employment for participants. The use of the decent work framework, although not prescriptive, provides a useful benchmark through which to identify and monitor access to jobs, security and quality of work, and rights of the worker.

\subsection{Use class-based analysis to understand socio-economic reasons underlying structural poverty}

Analysis of households containing formal and informal workers revealed a strong association between education level and income of workers. This suggests there is a class-based structure underlying the distribution of formal and informal workers within households. During a discussion session at the Working on the Margins workshop hosted by PLAAS in Cape Town in March 2009, Ben Cousins raised the important but neglected role of class analysis in the evaluation of structural causes of poverty.

\footnotetext{
${ }^{46}$ See ILO "Decent Work Agenda" at http://www.ilo.org/global/about-the-ilo/decent-work-agenda/ lang--en/index.htm (accessed 9 July 2011) - Editor.

47 Rodgers "The goal of decent work" (2008).

48 Rodgers "Labour market flexibility and decent work" (2008).

${ }^{49}$ Speech at ANC conference in Gauteng, November 2008: Sunday Times 30 November 2008.

50 Philip (2009).

${ }^{51}$ Philip (2009).

52 Booth (1998).
} 
Wright ${ }^{53}$ has developed a framework for measuring class structure and permeability. The class grid is based on dimensions of property, authority and skill. This framework could be extended to formal and informal work and would provide a useful tool to analyse linkages (permeability) between economies. Unfortunately, we cannot use the framework for the LFS datasets cited above because, while we have indicators measuring relation to means of production (owner, employee), and relation to scarce skills (experts, skilled, non-skilled), we do not have a clear measure of relation to authority (manager, supervisor, non-manager). We need a more nuanced measurement of work - in this case the inclusion of an indicator to measure relation to authority - to be able to test different, but potentially critical, paths of analysis.

\section{CONCLUSION}

According to Booth, ${ }^{54}$ state policy in the 1980 s was developed to create employment in the informal economy - through removing legislation and providing capital to entrepreneurs - as a temporary measure to alleviate unemployment. The growth of the informal economy and high unemployment rates imply that older and more recent policy has failed.

Poverty alleviation policies which are premised on viewing the economy as two distinct and unconnected parts of the economy are misguided. There is an urgent need to move away from viewing the formal and informal economy as dichotomies. This is not to suggest that the term is not useful. Rather, "formal" and "informal" need to be seen as part of a continuum, or as interacting sets, each with high levels of heterogeneity in the nature of economic activity.

Our analysis suggests that at the lower end of the labour market in South Africa there is a large amount of movement between formal and informal employment. The International Conference of Labour Statistics has proposed a new concept of the informal economy which takes the nature of the employment (and not the nature of the enterprise as is currently the case) to distinguish between formal and informal employment ${ }^{55}$. Our data, and the high levels of churning at the lower end of the labour market, suggest that the concept of the informal economy remains very useful for studies of poverty.

Longitudinal panel data may give us a lot of new insight into the nature of work and on the work-related activities of vulnerable workers. The panel data that we have used is a pilot project for Statistics South Africa. We suggest that the LFS panel be made available to researchers and that adequate documentation be released so that researchers are able to interrogate and use the data.

Finally, our analysis suggests that, contrary to the views of Maloney and his collaborators, informal employment in the South African case at least is not a first

53 Wright Class Counts (1997).

54 Booth (1998).

55 See Chen et al Women, work and poverty (2005). 
choice for workers. While there are certainly some aspects of the informal economy which might be lucrative, and there may be some actors evading government regulation, the movements that we explore do not suggest that workers voluntarily move into the informal economy for higher incomes. 


\section{BIBLIOGRAPHY}

Altman M "The state of employment and unemployment" in Daniels J Habib A and Southall R (eds) State of the Nation: South Africa 2003-2004 HSRC Press (2003) 158.

Altman M and Mayer M Sector strategies for employment creation: construction, social services and food. Paper presented at the TIPS/DPRU annual forum 8-10 September 2003 Development Policy Research Unit (2003).

Booth D Measuring the 'success' of employment creation strategies in the apartheid state. Rural Urban Studies Series Working Paper No 13 Development Studies Unit (1988).

Budlender D Buwembo P Chobokoane $\mathrm{N}$ and Shabalala $\mathrm{N}$ The informal economy: statistical data and research findings; country case study: South Africa Community Agency for Social Enquiry (2001)

Chen M Vanek J and Carr M Mainstreaming informal employment and gender in poverty reduction Commonwealth Secretariat (2004).

Chen M Vanek J Lund F Heintz J Jhabvala R and Bonner C Women, work and poverty, progress of the world's women UNIFEM (2005).

Devey R Skinner C and Valodia I "Definitions, data and the informal economy in South Africa: a critical analysis" in Padayachee V (ed.) The development decade? Economic and social change in South Africa, 1994-2004 HSRC Press and Zed Books (2006) 302.

Devey R Skinner C and Valodia I "The state of the informal economy" in Buhlungu S Daniel J Latchman J and Southall R (eds) The State of the Nation 2005-2006 HSRC Press (2005) 223.

Fine B Labour market theory: a constructive reassessment Routledge (1998).

Guha-Khasnobis B Kanbur R and Ostrom E Linking the formal and informal economy: concepts and policies Oxford University Press (2006).

Hart K "Informal income opportunities and urban employment in Ghana" (1973) 11(1) Journal of Modern African Studies) 61.

Ince M Nature of informal clothing manufacturing in a residential area: the case of Chatsworth Unpublished Masters thesis University of Natal (2003).

International Labour Office Women and men in the informal sector: a statistical picture ILO (2002).

Kenny B "Militant divisions, collective possibilities: lessons for labour mobilization from South African retail sector workers" (2005) 38 1-2 Labour, Capital \& Society 56. 
Lebani L and Valodia I (2005) The dynamics of employment and poverty in South Africa: an empirical enquiry based on the KwaZulu-Natal Income Dynamics Survey Working Paper School of Development Studies.

Legassick M "South Africa: Capital Accumulation and Violence" (1974) III Economy and Society 253.

Leibbrandt M Woolard I Finn A and Argent J Trends in South African income distribution and poverty since the fall of apartheid OECD (2010).

Ligthelm A "A targeted approach to informal business development: the entrepreneurial route" (2008) 25 (4) Development Southern Africa 367.

Lipton M Capitalism and Apartheid: South Africa, 1910-1986 Wildwood House (1985).

Maloney W “Informality Revisited” (2004) 32(7) World Development 1159.

Naidoo D van Aardt CJ and Ligthelm A Linkages between the formal and informal sectors in South Africa: An input-output table approach Bureau for Market Research UNISA (2004).

O'Dowd M "The Stages of Economic Growth and the Future of South Africa" in Schlemmer L and Webster E (eds) Change, reform and economic growth in South Africa Ravan Press (1978).

Phelps E with Hoon H T Kanaginis G and Zoega G Structural slumps: the modern equilibrium theory of unemployment, interest and assets Harvard University Press (1994).

Philip K Second economy strategy: addressing inequality and economic marginalisation. A strategic framework document for a Presidency TIPS Online www.tips.org.za Accessed 8/04/2009 (2009).

Ranger T "The invention of tradition in colonial Africa" in Hobsbawm E and Ranger $\mathrm{T}$ (eds) The invention of tradition (1983).

Rodgers G "The goal of decent work" (2008) 39 (2) IDS Bulletin 63.

Rodgers G "Labour Market Flexibility and Decent Work" in Ocampo J A and Jomo K S Towards full and decent employment. Orient Longman (2007) 191.

Skinner C Constraints to growth and employment in Durban: evidence from the informal economy Research Report Number 65 School of Development Studies (2005).

Skinner C and Valodia I "Labour market policy, flexibility, and the future of labour relations: the case of KwaZulu-Natal clothing industry" (2002) 50 Transformation 56.

Statistics South Africa Profiling South African middle-class households, 1998-2006 Report No. 03-03-01 (2009). 
Svendsen L Work Acumen (2008).

Theron J and Godfrey S Protecting workers on the periphery Development and labour monograph University of Cape Town (2000).

Tokman V "An exploration into the nature of informal-formal sector relationships" (1978) 6 (9/10) World Development 1065.

Valodia I Davies R Altman M and Thurlow J Exploring economic behavior in South Africa's informal economy, especially in relation to the formal economy Human Sciences Research Council (2007).

Webster E “The Dual Economy” (2004) 15 New Agenda 13.

Witt $\mathrm{H}$ "Fresh produce distribution networks in the Durban metropolitan area; in Freund B and Padayachee V (D)Urban Vortex: South African city in transition University of Natal Press (2003).

Wolpe $\mathrm{H}$ "Capitalism and cheap labour-power in South Africa: from segregation to apartheid" (1972) I Economy and Society 425.

Wright EO Class counts: comparative studies in class analysis Cambridge University Press (1997). 